Vol. 10 No.2 Des 2020, hal 25-37

Rudy Kurniawan

\title{
ANALISIS PERBEDAAN LAPORAN KEUANGAN PADA KLUB SEPAK BOLA \\ (Studi Pada Klub Sepak bola Di Liga Inggris, Liga Spanyol, dan Liga Italia)
}

\author{
Rudy Kurniawan*,Syf Annisa Wahidania** \\ Fakultas Ekonomi Universitas Tanjungpura, Pontianak
}

\begin{abstract}
$\underline{\text { ABSTRAK }}$
Penelitian ini bertujuan untuk menganalisis perbedaan dalam laporan keuangan pada klub sepak bola di liga Inggris, Spanyol dan Italia. Penelitian ini dilakukan dengan menggunakan deskriptif kualitatif melalui studi kasus pada klub sepak bola di liga Inggris, Liga Spanyol dan Liga Italia. Analisis laporan keuangan dan dokumen terkait diperoleh langsung dari situs resmi klub masing-masing. Hasil penelitian ini menunjukkan bahwa masing-masing klub dari tiga liga tersebut menggunakan acuan yang berbeda dalam penyajian laporan keuangan. Namun, informasi yang disajikan oleh masing-masing klub telah memenuhi kriteria minimum yang disyaratkan oleh kriteria keuangan UEFA dalam hal penyajian informasi laporan keuangan.
\end{abstract}

Kata kunci : laporan keuangan, komponen keuangan, klub sepak bola

\section{PENDAHULUAN}

Dalam sebuah perusahaan bentuk informasi yang didapat dalam bidang ekonomi adalah laporan keuangan. Laporan keuangan merupakan catatan informasi keuangan suatu perusahaan pada suatu periode akuntansi yang dapat digunakan sebagai dasar pengambilan keputusan. Menurut Internasional Accounting Standard (IAS) tujuan laporan keuangan ialah untuk memberikan informasi mengenai posisi keuangan, kinerja, dan perubahan posisi keuangan suatu entitas yang berguna untuk cakupan yang luas dari para pengguna dalam pengambilan keputusan ekonomi.

Banyak pihak yang berkepentingan dengan laporan keuangan, diantaranya para investor dan kreditor menggunakannya untuk menilai prospek perusahaan untuk keputusan investasi dan pinjaman. Para pemilik perusahaan akan berkepentingan untuk dapat menilai sukses atau tidaknya manajer yang diberi kepercayaan orang pemegang saham untuk mengendalikan perusahaannya. Pemerintah, berkepentingan terhadap informasi akuntansi suatu perusahaan yang berkaitan dengan masalah perpajakan. Dari laporan keuangan yang ada, pemerintah dapat menentukan jumlah pajak dan penetapan pajak dari perusahaan tersebut. Serta para karyawan, memerlukan informasi akuntansi yang didapat dari laporan keuangan untuk mengetahui profitabilitas dan akuntabilitas perusahaan tempat mereka bekerja.

Perkembangan dunia bisnis tidak hanya sebatas pada sektor manufaktur, perdagangan, maupun perbankan saja, namun seiring bergulirnya waktu bidang olahraga pun kini telah menjadi lahan bisnis baru yang menjanjikan, seperti yang dapat dilihat pada industri sepak bola. Sesungguhnya hanya beberapa negara saja yang menerapkan sepakbola sebagai sebuah industri yang menjanjikan, misalnya negara Inggris, Italia dan Spanyol. Sementara di negara lain termasuk Indonesia belum dapat disebut sebagai industri. Klub-klub yang ada di Indonesia kebanyakan dimiliki oleh daerah masingmasing serta berada di bawah pemerintah daerah.

Industri Sepak Bola adalah industri yang memiliki berbagai keunikan. Keunikan industri sepak bola tidak terlepas dari masalah akuntansi yang melekat di dalamnya. Misalnya terkait dengan pengungkapan para pemain di dalam laporan keuangan, pengakuan atas biaya-biaya yang timbul akibat dari adanya transfer pemain, dan mengenai hak siar pertandingan. Konsep akuntansi yang 
digunakan pada industri sepak bola menjadi pembeda antara laporan keuangan industri sepak bola dengan laporan keuangan industri lain.

Federation Internasionale de Football Association (FIFA) selaku badan tertinggi dalam sepak bola menyatakan bahwa pada prinsipnya laporan keuangan sepakbola disusun sesuai dengan kriteria tertentu yang telah ditetapkan dan memenuhi standar minimal pelaporan yang telah ditetapkan oleh FIFA yang disebut financial criteria. FIFA menyatakan bahwa penyiapan dan penyajian laporan keuangan bisa berbeda tiap entitas pada negara yang berbeda karena perbedaan sosial, ekonomi dan dalam peraturan perundangan sehingga implementasi dari financial criteria dalam peraturan pada masing-masing negara akan memberikan tantangan bagi anggota, baik asosiasi maupun klub. Sehingga apa yang terdapat dapat regulasi FIFA tersebut bukanlah standar akuntansi mengenai bentuk pelaporan keuangan, melainkan hanya sebatas kriteria pelaporan yang harus dipenuhi dan informasi minimal yang harus diungkapkan dalam laporan keuangan klub. Karena hanya sebatas kriteria pelaporan saja yang harus dipenuhi maka terjadi ketidakseragaman dalam penyajian laporan keuangan. Perbedaan tersebut bisa berupa perbedaan acuan dalam penyiapan dan penyusunan laporan keuangan serta dalam susunan item - item pada neraca maupun dalam laporan laba rugi.

\section{TINJAUAN PUSTAKA}

Maraknya industri persepakbolaan dalam beberapa waktu terakhir ini telah melahirkan banyak klub-klub dengan pendapatan yang sangat fantastis, bahkan dapat mencapai lebih dari dua ratus juta dollar pertahunnya. Pendapatan dalam industri sepak bola terutama berasal dari tiket pertandingan, penjualan hak siar kepada media, sponsorship serta penjualan berbagai merchandise klub. (Devi,2004) Hidayat (2010) menjelaskan bahwa di benua Eropa, terutama liga-liga utama seperti Liga Inggris, Liga Italia dan Liga Spanyol, sepakbola merupakan bagian dari industri sehingga dikelola secara profesional dan dikemas sedemikian rupa untuk dijual ke seluruh belahan dunia. Sementara Haryoprasetyo (2013) berpendapat bahwa kepopuleran sepakbola sudah merubah sepakbola menjadi sebuah industri baru di dunia. Sepakbola tidak lagi hanya sebagai permainan atau cabang olahraga, tetapi sepakbola sudah menjadi sebuah bisnis yang menguntungkan bagi beberapa pihak. Bahkan sepakbola sudah menarik perhatian bagi beberapa miliarder dunia untuk memiliki salah satu dari klub sepakbola profesional. Sebagai contoh Roman Abramovich yang memiliki klub Inggris Chelsea, Tony Fernandes yang sekarang menjadi pemilik klub Queens Park Rangers, bahkan Thohir yang notabene seorang pengusaha asal Indonesia memilih untuk mengakuisisi klub sepakbola Intermilan.

Industri sepakbola memiliki prospek yang bagus dikarenakan karakteristik unik yang dimilikinya. Bisnis persepakbolaan dapat mempengaruhi konsumennya secara emosional, bahkan terkadang tidak rasional (Devi,2004). Karena loyalitas konsumen mereka tidak diragukan, baik klub sepak bola tersebut dalam kondisi menang ataupun kalah. Karakteristik unik tersebut yang tidak dimiliki oleh jenis industri lainnya. Untuk klub-klub yang berbentuk Publik Limited Company (PLCs) maka pendukung fanatik tersebut juga memiliki saham klub. Hal ini dapat dilihat ketika Thohir, seorang pengusaha asal Indonesia memutuskan untuk mengakuisisi klub Intermilan yang merupakan klub favoritnya.Untuk memenuhi karakteristik dapat diperbandingkan (comparability), IASB menyusun International Accounting Standards (IAS) 1 tentang Presentation of Financial Statements. IAS 1 menetapkan dasar-dasar bagi penyajian laporan keuangan yang bertujuan secara umum untuk dapat dibandingkan baik dengan laporan keuangan entitas periode sebelumnya maupun dengan keuangan laporan entitas lain. IAS 1 ini menetapkan persyaratan keseluruhan untuk penyajian laporan keuangan, pedoman untuk struktur dan persyaratan minimum untuk laporan keuangan perusahaan. Menurut IAS 1 komponen laporan keuangan yang lengkap terdiri dari :

a) Laporan perubahan posisi keuangan (statement of financial position) pada akhir periode

b) Laporan laba-rugi komprehensif (statement of comprehensive income) untuk satu periode

c) Laporan perubahan modal (statement of change in equity) untuk satu periode

d) Laporan arus kas (statement of cash flow) untuk satu periode 
e) Catatan atas laporan keuangan (Notes), terdiri dari sebuah ringkasan atas kebijakan akuntansi yang penting dan informasi penjelas lainnya, dan

f) Laporan posisi keuangan awal periode komparatif sajian akibat penerapan retrospektif, penyajian kembali, atau reklasifikasi pos-pos laporan keuangan.

\section{METODE PENELITIAN}

Bentuk penelitian yang digunakan dalam penelitian ini adalah penelitian kualitatif dan bersifat deskriptif. Dalam penelitian ini peneliti mengumpulkan data dari laporan keuangan dari masingmasing klub sepakbola yang diteliti, serta menggunakan Studi Pustaka (Library Research) yaitu penulis membaca referensi yang mendukung isi penelitian ilmiah yang berasal dari buku, website atau artikel yang berkaitan dengan pembahasan penelitian yang sedang diteliti, struktur organisasi perusahaan, dan informasi yang berhubungan dengan laporan keuangan pada industri sepakbola.

\section{PEMBAHASAN}

Pada penelitian ini, analisis perbedaan laporan keuangan dilakukan penulis terhadap semua sampel yang diteliti yaitu dari Liga Inggris (Manchester United PLC dan Arsenal Holding PLC), Liga Spanyol (Real Madrid club de futbol dan Futbol Club Barcelona) serta Liga Italia (AC Milan S.p.A dan Juventus Football Club S.p.A). Pada masing-masing sampel terdapat perbedaan pada aktivitas bisnis yang digeluti. Namun secara garis besarnya masing-masing klub yang diteliti bergerak dalam segmen yang sama yaitu mengelola klub sepakbola professional. Pada klub Manchester united PLC dan Arsenal Holding PLC sama-sama klub sepakbola yang berbentuk Public Limited Company (PLC). Pada perusahaan yang berbentuk PLC, sahamnya dapat dijual bebas dan diperdagangkan kepada publik. Pada klub Real Madrid dan Barcelona sama-sama klub yang bersifat privat. Dimana klub-klub tersebut dimiliki oleh para anggotanya yang disebut socios. Sementara AC Milan S.p.A. dan Juventus S.p.A. adalah perusahaan yang berbentuk publik serta sama-sama mengelola klub sepakbola professional. Hanya saja pada klub AC. Milan selain aktivitas utamanya yang mengelola klub sepakbola professional, AC. Milan juga menggeluti beberapa bisnis lain seperti estate dan entertainment.

\section{Tabel 4.1}

Perbandingan aktifitas utama sampel

\begin{tabular}{|c|c|c|c|c|}
\hline No & $\begin{array}{l}\text { Liga } \\
\text { Eropa }\end{array}$ & Nama Klub & Aktifitas utama & $\begin{array}{l}\text { Sifat perusahaan } \\
\text { klub sepakbola }\end{array}$ \\
\hline 1. & \multirow{2}{*}{ 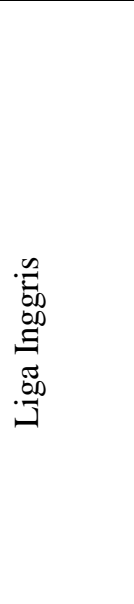 } & Manchester United PLC & $\begin{array}{l}\text { Merupakan perusahaan yang } \\
\text { berbentuk public limited } \\
\text { company yang mendapatkan } \\
\text { pendapatan melalui tiga } \\
\text { sektor utama yaitu } \\
\text { komersial, penyiaran dan } \\
\text { matchday. }\end{array}$ & $\begin{array}{l}\text { Public Limited } \\
\text { Company (PLC) }\end{array}$ \\
\hline 2. & & $\begin{array}{l}\text { Arsenal Holding } \\
\text { PLC }\end{array}$ & $\begin{array}{l}\text { Merupakan holding dari } \\
\text { beberapa perusahaan yang } \\
\text { aktifitas utamanya ialah } \\
\text { pengelolaan klub sepakbola } \\
\text { profesional dan properti. }\end{array}$ & $\begin{array}{l}\text { Public Limited } \\
\text { Company (PLC) }\end{array}$ \\
\hline 3. & ב 茄 की & Real Madrid Club de Fútbol, & $\begin{array}{l}\text { Aktivitas utama ialah bisnis } \\
\text { persepakbolaan dan basket. }\end{array}$ & Privat \\
\hline
\end{tabular}




\begin{tabular}{|c|c|c|c|c|}
\hline 4. & & $\begin{array}{l}\text { Futbol Club } \\
\text { Barcelona }\end{array}$ & $\begin{array}{l}\text { Pengelolaan klub sepakbola } \\
\text { profesional, serta beberapa } \\
\text { cabang } \\
\text { olahraga lain }\end{array}$ & Privat \\
\hline 5. & \multirow{2}{*}{ 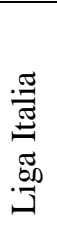 } & $\begin{array}{lll}\text { Associazione } & \text { Calcio } & \text { Milan } \\
\text { S.p.A. } & & \end{array}$ & $\begin{array}{l}\text { Pengelolaan klub sepakbola } \\
\text { profesional, serta beberapa } \\
\text { bisnis lain seperti estate dan } \\
\text { entertainment }\end{array}$ & Publik \\
\hline 6. & & $\begin{array}{l}\text { Juventus Football } \\
\text { Club S.p.A. }\end{array}$ & $\begin{array}{l}\text { Pengelolaan klub } \\
\text { sepakbola professional. }\end{array}$ & Publik \\
\hline
\end{tabular}

Sumber: Data yang Diolah

\subsection{Perbandingan Tempat Listing dan Pemilik Klub}

Pada masing-masing klub yang diteliti adalah klub dengan status yang berbeda. Pada Liga Inggris sampel yang diteliti ialah Manchester United PLC dan Arsenal Holding PLC yang merupakan klub yang berstatus Public Limited Company $(P L C)$. Saham Manchester United PLC diperjualbelikan di New York Stock Exchange (NYSE) sementara saham Arsenal Holding PLC diperjualbelikan di PLUS. Pada Liga Spanyol, Real Madrid Club de Fútbol dan Futbol Club Barcelona merupakan klub sepakbola yang berstatus privat. Dimana, klub sepakbola tersebut dimiliki oleh para anggota yang disebut socios. Socios adalah anggota resmi Real Madrid dan Barcelona. Para anggota tersebut (socios) memiliki kewajiban membayar iuran tiap bulannya dan memiliki hak sebagai berikut:

1. Memilih \& menurunkan Presiden

2. Mempunyai hak suara dalam manajemen klub

3. Potongan harga tiket Socios juga bisa dapat pinjaman dari bank sponsor. Misalnya pada klub Real Madrid yang memberikan para sociosnya potongan harga tiket serta mendapat pinjaman dari bank sponsor dengan bunga yang ringan.

Syarat menjadi Socios :

1. Kewarganegaraan Spanyol

2. Isi pendaftaran

3. Di seleksi dan setiap tahun ada ribuan pendaftar, dan hanya menerima anggota baru 15-20 orang.

Sementara di Liga Italia, klub Associazione Calcio Milan S.p.A. dan Juventus Football Club S.p.A sama-sama merupakan klub yang bersifat publik. Pada klub Associazione Calcio Milan S.p.A. pemilik klub adalah mantan Perdana Menteri Italia dan pemegang saham pengendali Mediaset Silvio Berlusconi, dan wakil presiden adalah Adriano Galliani. Disisi lain Juventus Football Club S.p.A mencatatkan sahamnya di Borsa Italiana dan dimiliki oleh berbagai pihak yaitu Exor S.p.A. (63,8\%), Lindsell Train Ltd $(2,2 \%)$ dan pemegang saham lain (34\%). Perbandingan mengenai tempat listing dan pemilik masing-masing klub tersebut diikhtisarkan pada tabel 4.2 di bawah ini. 
Vol. 10 No.2 Des 2020, hal 25-37

Rudy Kurniawan

Tabel 4.2

Perbandingan tempat listing dan pemilik perusahaan klub sepak bola yang dijadikan sampel

\begin{tabular}{|c|c|c|c|c|}
\hline No & $\begin{array}{l}\text { Liga } \\
\text { Eropa }\end{array}$ & Nama Klub & Tempat Listing & Pemilik Perusahaan \\
\hline 1. & & Manchester United PLC & $\begin{array}{l}\text { New York Stock } \\
\text { Exchange (NYSE) }\end{array}$ & $\begin{array}{l}\text { Pemilik: Keluarga Glazer } \\
\text { serta Martin Edwards sebagai } \\
\text { Presiden Direktur. }\end{array}$ \\
\hline 2. & 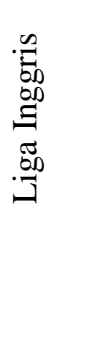 & Arsenal Holding PLC & $\begin{array}{l}\text { Diperdagangkan di } \\
\text { PLUS }\end{array}$ & $\begin{array}{l}\text { Stan Kroenke } \\
(28.5 \%), \text { Danny } \\
\text { Fiszman }(16,1 \%), \\
\text { Nina Bracewell- } \\
\text { Smith }(15,9 \%) \text {, Red } \\
\text { \& White Securities } \\
\text { Ltd }(25,3 \%), \text { Peter } \\
\text { Hill-Wood }(0,64 \%) .\end{array}$ \\
\hline 3. & 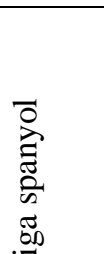 & Real Madrid Club de Fútbol & Tidak ada & $\begin{array}{l}\text { Dimiliki oleh para anggota } \\
\text { yang disebut socios. Socios } \\
\text { adalah anggota resmi Real } \\
\text { Madrid. Jumlah Socios Real } \\
\text { Madrid saat ini ada } 92.600 \\
\text { socios. }\end{array}$ \\
\hline 4. & $\Xi$ & Futbol Club Barcelona & Tidak ada & $\begin{array}{l}\text { Anggota } \\
\text { Klub/socios } \\
\text { (172.938 orang) }\end{array}$ \\
\hline 5. & 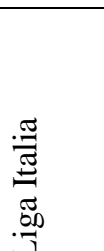 & Associazione Calcio Milan S.p.A & - & $\begin{array}{l}\text { Pemilik klub adalah mantan } \\
\text { Perdana Menteri Italia dan } \\
\text { pemegang saham pengendali } \\
\text { Mediaset Silvio Berlusconi, } \\
\text { dan wakil presiden adalah } \\
\text { Adriano Galliani. }\end{array}$ \\
\hline 6. & & Juventus Football Club S.p.A. & $\begin{array}{l}\text { Saham Juventus } \\
\text { dicatatkan di Borsa } \\
\text { Italiana }\end{array}$ & $\begin{array}{l}\text { Exor S.p.A. }(63,8 \%) \text {, Lindsell } \\
\text { Train Ltd }(2,2 \%) \text { dan } \\
\text { pemegang saham lain }(34 \%) \text {. }\end{array}$ \\
\hline
\end{tabular}

Sumber: Data yang Diolah

\subsection{Perbandingan Komponen Laporan Keuangan}

Perbedaan status pada setiap sampel yang diteliti penulis pada akhirnya membawa perbedaan terhadap format maupun kompleksitas dari laporan keuangan yang dihasilkan oleh setiap klub sepakbola. Hal ini dinilai wajar karena perusahaan yang go public jelas dituntut lebih dalam hal transparansi sebagai konsekuensi dari penerapan Good Governance. Berbeda halnya dengan klub yang dimiliki oleh para anggota (socios) yang dalam penelitian ini terjadi pada klub Real Madrid dan Futbol Club Barcelona yang bukanlah berbentuk Public Limited Company (PLC) sehingga biasanya semua laporan ekonomi adalah untuk penggunaan internal dan tidak ada kewajiban dari klub untuk mempublikasikan laporan keuangan mereka kepada publik.

Pada umumnya perusahaaan yang mengakhiri periode akuntansinya pada tanggal 31 Desember, namun setiap klub sepakbola yang diteliti penulis memiliki perbedaan dalam mengakhiri periode akuntansinya. Pada Liga Inggris, klub Manchester United pada tanggal 30 Juni dan Arsenal mengakhiri laporan keuangannya pada tanggal 31 Mei. Pada Liga spanyol, klub Real Madrid dan Barcelona sama-sama mengakhiri laporan keuangannya pada tanggal 30 Juni. Sementara hal berbeda terjadi pada Liga Italia, klub Juventus pada tanggal 30 Juni dan AC Milan pada tanggal 31 Desember. 
Hal ini tidak terlepas dari siklus bisnis klub sepakbola yang berbeda-beda. Seperti diketahui bahwa waktu bergulirnya liga-liga di Eropa diatur oleh UEFA karena disesuaikan dengan kalender kegiatan UEFA dan FIFA. Liga Eropa biasanya dimulai pada sekitar bulan Agustus September dan berakhir pada sekitar bulan Mei tahun berikutnya.

Tabel 4.3

Perbandingan Laporan Keuangan

\begin{tabular}{|c|c|c|c|c|c|c|}
\hline No & Nama Klub & $\begin{array}{l}\text { Liga } \\
\text { Eropa }\end{array}$ & $\begin{array}{c}\text { Tanggal } \\
\text { pelaporan }\end{array}$ & Laporan keuangan & $\begin{array}{l}\text { Mata uang } \\
\text { pelaporan }\end{array}$ & $\begin{array}{c}\text { Acuan dalam } \\
\text { Penyiapan \& } \\
\text { Penyusunan } \\
\text { Laporan } \\
\text { Keuangan }\end{array}$ \\
\hline 1. & Manchester United PLC & & 30 Juni & $\begin{array}{l}\text { a) Consolidated } \\
\text { Income statement } \\
\text { b) Consolidated } \\
\text { Statement of } \\
\text { Comprehensive } \\
\text { Income } \\
\text { c) Consolidated } \\
\text { Balance sheet } \\
\text { d) Consolidated } \\
\text { Statement Of } \\
\text { Changes In Equity } \\
\text { e) Consolidated } \\
\text { Statement of Cash } \\
\text { Flows }\end{array}$ & $\begin{array}{l}\text { Poundsterling } \\
\text { (£) }\end{array}$ & $\begin{array}{c}\text { IFRS yang } \\
\text { dikeluarkan oleh } \\
\text { IASB }\end{array}$ \\
\hline 2. & $\begin{array}{l}\text { Arsenal Holding } \\
\text { PLC }\end{array}$ & 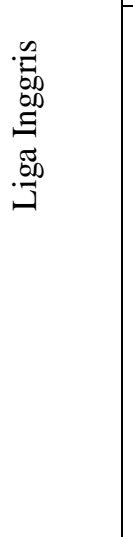 & $31 \mathrm{Mei}$ & $\begin{array}{l}\text { a) Consolidated } \\
\text { Profit and Loss } \\
\text { Account } \\
\text { b) Balance Sheet } \\
\text { c) Consolidated Cash } \\
\text { Flow Statement }\end{array}$ & $\begin{array}{l}\text { Poundsterling } \\
(\mathfrak{E})\end{array}$ & $\begin{array}{l}\text { United Kingdom } \\
\text { Generally } \\
\text { Accepted } \\
\text { Accounting } \\
\text { Practice } \\
\text { (UK GAAP) } \\
\text { atau UK } \\
\text { Accounting } \\
\text { Standards serta } \\
\text { sesuai dengan } \\
\text { persyaratan } \\
\text { Companies Act } \\
\text { 2006. }\end{array}$ \\
\hline No & Nama Klub & $\begin{array}{l}\text { Liga } \\
\text { Eropa }\end{array}$ & $\begin{array}{c}\text { Tanggal } \\
\text { pelaporan }\end{array}$ & Laporan keuangan & $\begin{array}{l}\text { Mata uang } \\
\text { pelaporan }\end{array}$ & $\begin{array}{c}\text { Acuan dalam } \\
\text { Penyiapan \& } \\
\text { Penyusunan } \\
\text { Laporan } \\
\text { Keuangan }\end{array}$ \\
\hline 3. & Real Madrid & ב & 30 Juni & $\begin{array}{l}\text { a) Neraca (Balance } \\
\text { de situacion) }\end{array}$ & Euro $(€)$ & - \\
\hline
\end{tabular}




\begin{tabular}{|c|c|c|c|c|c|c|}
\hline & & & & $\begin{array}{l}\text { b) Angggaran } \\
\text { konsolidasi } \\
\text { (Presupuesto } \\
\text { consolidado) }\end{array}$ & & \\
\hline 4. & $\begin{array}{l}\text { Futbol Club } \\
\text { Barcelona }\end{array}$ & & 30 Juni & $\begin{array}{l}\text { a) Balance Sheet } \\
\text { b) Income Statement } \\
\text { c) Statement of } \\
\text { Change in Equity } \\
\text { d) Statement of Cash } \\
\text { Flow }\end{array}$ & Euro $(€)$ & $\begin{array}{l}\text { Peraturan } \\
\text { kerangka } \\
\text { pelaporan } \\
\text { keuangan yang } \\
\text { berlaku pada } \\
\text { Club. }\end{array}$ \\
\hline 5. & AC Milan & & $\begin{array}{l}31 \\
\text { Desember }\end{array}$ & 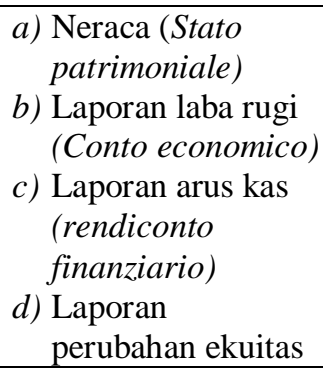 & Euro $(€)$ & $\begin{array}{l}\text { Ketentuan } \\
\text { bercabang dari } \\
\text { Federasi } \\
\text { Sepakbola Italia } \\
\text { dan Komisi } \\
\text { Pengawas } \\
\text { Perusahaan } \\
\text { Sepakbola } \\
\text { Profesional. }\end{array}$ \\
\hline 6. & $\begin{array}{l}\text { Juventus Football } \\
\text { Club S.p.A. }\end{array}$ & 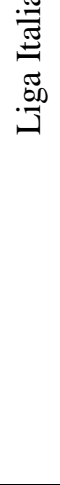 & 30 Juni & $\begin{array}{l}\text { a) Statement of } \\
\text { financial position } \\
\text { b) Income Statement } \\
\text { c) Statement of } \\
\text { Comprehensive } \\
\text { Income } \\
\text { d) Statement of } \\
\text { Changes in } \\
\text { Shareholders' } \\
\text { equity } \\
\text { e) Statement of Cash } \\
\text { Flows }\end{array}$ & Euro $(€)$ & $\begin{array}{l}\text { IFRS yang } \\
\text { dikeluarkan oleh } \\
\text { IASB }\end{array}$ \\
\hline
\end{tabular}

Sumber: Laporan Keuangan Masing-Masing Klub

Dalam menyajikan laporan keuangan masing-masing klub sedikit berbeda dan terjadi ketidakseragaman, baik itu di liga Inggris, Spanyol maupun Italia. Hal ini dikarenakan dalam peraturan FIFA bukanlah standar akuntansi mengenai bentuk pelaporan keuangan sehingga dalam penyiapan dan penyajian laporan keuangan bisa berbeda tiap entitas pada negara yang berbeda karena terdapat perbedaan sosial, ekonomi dan peraturan perundangan.

\subsection{Liga Inggris}

Pada Liga Inggris sampel yang diteliti penulis ialah Manchester United PLC dan Arsenal Holding PLC. Pada klub Manchester United PLC merupakan klub yang berasal dari Inggris yang berbentuk Public Limited Company. Sementara Arsenal Holding PLC adalah klub yang merupakan holding dari beberapa perusahaan yang aktivitas utamanya ialah pengelolaan klub sepakbola profesional dan juga properti. Kedua sampel yang diteliti penulis sama - sama diperjualbelikan di pasar saham namun terdapat perbedaan dalam tempat listing saham klub tersebut. Saham Manchester United PLC diperjualbelikan di New York Stock Exchange (NYSE) sementara saham Arsenal Holding PLC diperjualbelikan di PLUS, sebuah pasar spesialis.

Sebagai acuan dalam penyusunan dan penyajian laporan keuangan Manchester United PLC berdasarkan IFRS yang dikeluarkan IASB sementara Arsenal lebih memilih untuk menggunakan United Kingdom Generally Accepted Accounting Practice (UK GAAP). Manchester United PLC mengakhiri periode akuntansinya pada tanggal 30 Juni sementara Arsenal Holding PLC pada tanggal 31 Mei. Pada klub Manchester United PLC laporan keuangannya terdiri dari Consolidated Income 
statement, Consolidated statement of comprehensive income, Consolidated Balance sheet, Consolidated Statement of Changes In Equity, serta Consolidated Statement of Cash Flows. Hal ini sesuai dengan yang disyaratkan oleh UEFA Club Licensing and financial fair play regulation. Sementara Arsenal Holding PLC laporan keuangannya terdiri dari Consolidated profit and loss account, Balance sheet dan Consolidated cash flow statement. Pada laporan keuangan Arsenal tidak terdapat laporan perubahan ekuitas (statement of changes in equity) dan laporan laporan laba-rugi komprehensif (statement of comprehensive income).

Pada Neraca Manchester United pada item non-current assets, aset terbesar ada pada item goodwill. Sementara dari neraca Arsenal dapat diketahui bahwa aset utama dari klub sepakbola ini adalah aset tetapnya (fixed assets). Aset tetap pada klub ini terdiri dari tangible fixed assets, intangible fixed assets, dan investment. Aset berwujud dan tak berwujud klub Arsenal dikelompokkan dalam aset tetap bukan dalam aset lancar. Kemungkinan hal ini terjadi karena dilihat dari sisi likuiditasnya jika dibandingkan dengan item-item yang terdapat dalam aset lancar. Dalam menyajikan kelompok liabilities, Manchester United mengelompokkan akun-akun tersebut dalam current liabilities dan non current liabilities sesuai dengan yang disyaratkan oleh UEFA Financial Criteria. Namun pada klub Arsenal sedikit berbeda, yang terdapat pada kelompok liabilities yaitu creditors: amounts falling due within one year, creditor: amounts falling due after more than one year, dan provisions for liabilities and charges. Hal ini bisa saja membuat para pembaca laporan keuangan klub Arsenal akan sedikit kebingungan, namun Catatan Atas Laporan Keuangan (CALK) Arsenal dapat memperjelas mengenai penyajian ketiga akun tersebut.

Pada klub Manchester United pendapatan berasal dari banyak sumber. Hal ini tercermin di laporan laba rugi manchester united PLC komponen yang paling dominan ialah komponen revenue yang terbagi menjadi tiga yaitu commercial revenue, broadcasting dan matchday. Sementara pada klub Arsenal pendapatan terbesar berasal dari penjualan tiket pertandingan (gate and other matchday revenue). Pada penyajian laporan arus kas, Manchester United menyajikannya kedalam tiga aktivitas utama seperti yang disyaratkan dalam UEFA Financial Criteria. Di sisi lain, laporan arus kas Arsenal hanya menyebutkan adanya akun net cash inflow from operating activities. Sementara untuk akunakun yang tergolong ke dalam aktivitas investasi dan pendanaan tidak dikelompokkan secara tegas. Namun, secara keseluruhan penyajian laporan keuangan pada klub Manchester United dan Arsenal sudah memenuhi ketentuan yang disyaratkan dalam UEFA Financial Criteria.

\subsection{Liga Spanyol}

Pada liga spanyol sampel yang diteliti penulis ialah FC Barcelona dan Real Madrid. Real Madrid dan Barcelona sama-sama klub yang bersifat privat. Dimana, klub sepakbola tersebut dimiliki oleh para anggota yang disebut socios. Real Madrid dan Futbol Club Barcelona yang bukanlah berbentuk Public Limited Company (PLC) sehingga biasanya semua laporan ekonomi adalah untuk penggunaan internal dan tidak ada kewajiban dari klub untuk mempublikasikan laporan keuangan mereka kepada publik. Pada Liga spanyol, klub Real Madrid dan Barcelona sama-sama mengakhiri laporan keuangannya pada tanggal 30 juni. Pada liga Spanyol, Futbol Club Barcelona menggunakan Peraturan kerangka pelaporan keuangan yang berlaku pada klub. Laporan keuangan telah disusun oleh Dewan sesuai dengan kerangka pelaporan keuangan yang berlaku untuk klub.

Dalam menyajikan neraca, pada dasarnya kedua klub tersebut sesuai yang di syaratkan oleh UEFA Financial Criteria. Walaupun pada penyajiannya terdapat sedikit perbedaan mengenai penamaan atas akun-akun tertentu. Pada laporan laba-rugi pada klub Barcelona, sumber pendapatan terbesar diperoleh dari Revenue from marketing and advertising. Sementara Real Madrid pada laporan tahunannya (Informe Annual) penulis tidak menemukan adanya laporan laba-rugi yang secara khusus ditampilkan untuk mengetahui sumber pendapatan dan beban klub tersebut. Pada Informe Annual hanya terdapat informasi mengenai Real Madrid yang dalam laporan keuangan musim 2011-2012 mencatat rekor pemasukan yang fantastis sehingga membuat klub ini menduduki posisi pertama peringkat klub berdasarkan pendapatan periode 2011/2012 versi Deloitte Football Money Language. Pendapatan ini berasal dari lini bisnis klub, stadium, hak siar televisi, dan pemasaran. 


\section{JAAKFE}

Vol. 10 No.2 Des 2020, hal 25-37

Rudy Kurniawan

Pada penyajian laporan arus kas klub Bercelona menyajikannya sesuai dengan format UEFA Financial Criteria. Barcelona mengelompokkan aktivitas arus kasnya ke dalam tiga aktivitas utama, yakni arus kas dari aktivitas operasi, arus kas dari aktivitas investasi serta arus kas dari aktivitas pendanaan. Sementara Real Madrid pada laporan tahunannya (Informe Annual) penulis tidak menemukan adanya laporan arus kas yang secara khusus ditampilkan untuk mengetahui arus kas masuk dan arus kas keluar.

\subsection{Liga Italia}

Pada Liga Italia klub yang diteliti ialah AC Milan dan Juventus football club S.p.A. Pada klub Juventus sebagai perusahaan yang terdaftar di Borsa Italiana S.p.A terikat dengan berbagai regulasi yang dikeluarkan oleh bursa tersebut, terutama sehubungan dengan transaksi saham dan pelaporan keuangan. Juventus mengakhiri periode akuntansinya pada tanggal 30 Juni sementara AC Milan pada tanggal 31 Desember. Hal ini tidak terlepas dari siklus bisnis klub sepakbola yang berbeda-beda. AC Milan yang menggunakan prinsip akuntansi yang direkomendasikan Federasi Sepakbola Italia serta klub Juventus yang lebih memilih untuk menggunakan IFRS. Sehingga dalam menyajikan laporan keuangan masing-masing klub sedikit berbeda dan terjadi ketidakseragaman.

Dalam laporan keuangannya, AC. Milan menyajikan laporan neraca dengan judul balance sheet (stato patrimoniale), sementara Juventus lebih memilih untuk memberi judul statement of financial position. Pada klub Juventus, aset yang terletak paling atas ialah players' registration rights, net. Item ini jumlahnya sebesar $€ 118.094 .687$ hampir mendekati item land and buildings sebesar $€ 127.023 .632$. Sementara pada Neraca AC Milan item intangible assets yang termasuk dalam Fixed assets memiliki peran yang sangat besar bagi Neraca AC Milan. Walaupun jika dibandingkan dengan tahun lalu terjadi penurunan. Namun item intangible assets ini tetap menjadi penyumbang terbesar bagi Neraca AC Milan.

Pada penyajian laporan laba rugi klub Juventus, sumber pendapatan terbesar berasal dari television and radio rights and media sementara pada klub AC Milan pendapatan terbesar berasal dari audiovisual yang merupakan bagian dari other revenue and income. Pada penyajian Laporan Arus Kas klub AC Milan dan Juventus sama-sama menyajikannya sesuai dengan format EUFA Financial Criteria. Kedua klub tersebut mengelompokkan aktivitas arus kas ke dalam tiga aktivitas utama, yakni arus kas dari aktivitas operasi, arus kas dari aktivitas investasi serta arus kas dari aktivitas pendanaan.

\section{KESIMPULAN DAN SARAN}

Penelitian ini bertujuan untuk mengetahui perbedaan laporan keuangan pada klub sepak bola di liga Inggris, liga Spanyol dan liga Italia. Setelah dilakukan analisis, maka dapat ditarik kesimpulan bahwa pada dasarnya laporan keuangan ketiga liga yang dijadikan sampel oleh penulis telah memenuhi kriteria minimal seperti yang disyaratkan oleh UEFA. Namun terdapat banyak perbedaan dalam penyajiannya. Perbedaan tersebut bisa berupa perbedaan acuan dalam penyiapan dan penyusunan laporan keuangan, perbedaan dalam susunan item-item pada neraca, laporan laba rugi maupun dalam laporan arus kas. Hal ini dapat dimaklumi karena menurut FIFA dalam penyiapan dan penyajian laporan keuangan bisa berbeda tiap entitas pada negara yang berbeda karena perbedaan sosial, ekonomi dan dalam peraturan perundangan yang berbeda pula. Pada masing-masing klub yang diteliti penulis terdapat perbedaan dalam aktivitas utama klub tersebut. Pada Manchester United PLC yang merupakan klub yang berstatus Public Limited Company (PLC) yang sahamnya diperjualbelikan di New York Stock Exchange (NYSE). Sehingga dalam laporan keuangannya Manchester United PLC harus memenuhi peraturan yang telah ditetapkan oleh NYSE. Disisi lain Arsenal Holding PLC merupakan holding dari beberapa perusahaan yang diperdagangkan di PLUS. Aktivitas utamanya ialah pengelolaan klub sepakbola professional dan properti. Dalam penyusunan dan penyajian laporan keuangan Arsenal lebih memilih untuk menggunakan UK GAAP. 


\section{JAAKFE}

Vol. 10 No.2 Des 2020, hal 25-37

Rudy Kurniawan

Penelitian ini memiliki berbagai keterbatasan diantaranya kurangnya literatur mengenai akuntansi untuk klub sepakbola sehingga penelitian mengenai akuntansi yang secara mendalam membahas mengenai klub sepakbola masih minim dan kurang detail. Selain itu sulitnya mendapatkan laporan keuangan publikasi dari masing-masing klub sepakbola dalam bahasa Inggris. Hal ini terjadi pada liga Spanyol yaitu klub Barcelona dan Real Madrid yang laporan keuangannya masih dalam bahasa Spanyol. Serta AC Milan dari liga Italia yang laporan keuangannya masih menggunakan bahasa Italia. Sehingga untuk mengatasi hal tersebut penulis menggunakan google translate. Pada penelitian ini penulis hanya membahas perbedaan laporan keuangan secara umum sehingga diharapkan penelitian selanjutnya lebih detail dalam membahas perbedaan laporan keuangan tersebut. Masing-masing klub yang diteliti penulis dalam hal menyajikan laporan keuangan relatif berbeda baik dari penggunaan acuan dalam penyajian dan penyusunan laporan keuangan, sisi format laporan keuangan, maupun pilihan untuk melaporkan item-item tertentu. Beberapa perbedaan mungkin dapat membuat pembaca laporan keuangan mengalami kesulitan ketika berusaha memahami laporan keuangan tersebut. Untuk itu perlu kiranya ketegasan dari regulator untuk mengarahkan klub-klub agar menggunakan acuan yang sama dalam penyusunan laporan keuangan klub sepak bola. Sehingga tidak hanya sebatas kriteria minimal saja yang harus dipenuhi. Yang pada akhirnya akan membuat para pembaca laporan keuangan akan dengan mudah membandingkan laporan keuangan dari seluruh klub sepak bola di dunia.

\section{REFERENCES}

Accounting Standards Board. 2004. Framework for the Preparation and Presentation of Financial Statements.

http://download.asb.co.za/download/Framework for the Preparation and Presentation of Financial Statements.pdf, retrieved on 13 Maret 2014

AC. Milan. Relazione E Bilancio al 31 Dicembre 2012. http://www.acmilan.com/uploads/club/bilancio2012/, retrieved on 17 September 2013

Arsenal Holdings PLC. Statement of Accounts and Annual Report 2011/2012. $\quad$ http://arsenal.com, retrieved on 17 september 2013.

Deloitte.2012. Football Money Language.

http://deloitte.com/, retrieved on 17 September 2013.

Devi,Astri Prima. 2004. Akuntansi untuk pemain sepak bola. Jurnal akuntansi dan keuangan Indonesia, departemen akuntansi FEUI,1,pp.38-53

FC Barcelona. Memoria 2011/2012.

http://media1.fcbarcelona.com/media/asset_publics/resources/000/029/279 loriginal/Memoria Club 2011-12 CAST baixa.v1348336406.pdf, retrieved on 17 September 2013

Federation Internationale de football Association, FIFA Regulation Club Licensing. http://FIFA.com/, retrieved on 22 Januari 2013.

Haryoprasetyo, Riza.2013. Analisis Atas Kinerja Finansial Klub Sepakbola Profesional : Studi

Kasus Pada Manchester United PLC. Diponegoro journal of accounting, volume 2, nomor 3.

Hidayat, Rokhmat Taufiq. 2010. Analisis Atas Laporan Keuangan Klub Sepakbola: Studi

Pada Klub Sepakbola Arsenal, Juventus, dan Bercelona. Fakultas Ekonomi

UniversitasIndonesia

http://accountingexplained.com/financial/statements/equity-statement, retrieved on 22 januari 2014

http://accounting-simplified.com/financial/statements/statement-of-financial-position.html, retrieved on 22 januari 2014

http://akuntansisepakbola.blogspot.com/2012/12/akuntansi-untuk-klub-sepakbola.html, retrieved on 7 maret 2014

http://akuntansisepakbola.blogspot.com/2012/12/akuntansi-untuk-pemainsepakbola.html, retrieved on 19 desember 2013 
http://dasar-akuntansi.blogspot.com/2009/09/laporan-arus-kas.html, retrieved on 19 desember 2013

http://en.wikipedia.org/wiki/Generally_accepted_accounting_principles, retrieved on 25 Maret 2014 http://en.wikipedia.org/wiki/Generally Accepted Accounting Principles \%28U K\%29, retrieved on 25 Maret 2014

http://en.wikipedia.org/wiki/Generally_Accepted_Accounting_Principles_\%28United_States $\% 29$, retrieved on 25 Maret 2014

http://id.wikipedia.org/wiki/Laporan_keuangan, retrieved on 9 januari 2014

http://kambingterbang26.blogspot.com/2013/03/jenis-perbedaan-antara-ifrs-dengan us 1235.html, retrieved on 25 Maret 2014

http://keuanganlsm.com/objektif-dari-laporan-keuangan/ retrieved on 8 maret 2014

http://lailyza.blogspot.com/2012/04/pengguna-laporan-keuangan.html, retrieved on 8 maret 2014

http://nicolashadi.wordpress.com/author/nicolashadi/ retrieved on 8 maret 2014

http://ridwaniskandar.files.wordpress.com/2009/05/24-pihak-yg-berkepentingan.pdf, retrieved on 7 januari 2014

http://ropeng-watun.blogspot.com/2011/04/pelaporan-dan-pengungkapan-ifrs-dan 03.html, retrieved on 25 Maret 2014

http://www.bambanghariyanto.com/2013/09/pengertian-laporan-keuangan-arus kas.html, retrieved on 7 Januari 2014

http://www.bambanghariyanto.com/2013/09/perbedaan-penyusunan-arus-kas-metode- langsungdan-tidak-langsung.html, retrieved on 7 Januari 2014

http://www.iasplus.com/en/standards/other/framework, retrieved on 7 Januari 2014

http://www.investopedia.com/terms/c/comprehensiveincome.asp, retrieved on 22 Januari 2014

International Accounting Standard 1. 2011. Presentation of Financial Statements EC staff consolidated version as of 18 February 2011.

Juventus Football Club S.p.A. Annual Financial Report 30.06.2012. http://juventus.com/. retrieved on 22 januari 2014.

Kieso, Donald E., Weygandt, Jerry J., and Terry D Warfield. 2008. Intermediate Accounting, International Student Version. 12th ed. John Wiley \& Sons., Norwalk, Connecticut.

Manchester United PLC. Annual Report Pursuant To Section 13 Or 15(D) of The Securities Exchange Act Of 1934 for The Fiscal Year Ended June 30, 2012.

Moleong, Lexy J. 2010. Metodologi Penelitian Kualitatif. Bandung: PT. Remaja Rosdakarya.

Pedoman Penyusunan dan Penulisan Skripsi Program Sarjana. 2013. Fakultas Ekonomi Universitas Tanjungpura Pontianak.

Prihadi, Toto . 2010. Analisis Laporan Keuangan. Jakarta : ppm manajemen.

Real Madrid C. F. Informe Annual 2011-2012.

Real Madrid C. F. Group Management Report 2012-2013.

Satori, Djam'an dan Aan Komariah. 2010. Metodologi Penelitian Kualitatif. Bandung : CV. Alfabeta.

Sekaran, Uma. 2006. Research Methods for Business: Metodologi Penelitian untuk Bisnis Buku 1. Salemba Empat: Jakarta.

Siddik, Muhammad Hananto. 2013.Mencari Format Laporan Keuangan Yang Sesuai dengan Klub Sepak Bola Di Indonesia: Studi Kasus Pada Klub Sepak Bola Persema. Diponegoro journal of accounting, volume2, nomor 3

Kuncoro, Mudrajad dan Suhardjono, . 2002. Manajemen Perbankan Teori dan Aplikasi Edisi Pertama, BPFE, Yogyakarta.

The Eunion of European Football Association. UEFA Club Licensing and Financial Fair Play Regulation Edition 2012. http://uefa.com/, retrieved on 22 januari 2014.

Warren, carll F.;James F. Reeve; dan Philip E. Fess.2005. Accounting, 21th ed. Cincinnati, OH:South-Western Thompson learning. 
JAAKFE

Vol. 10 No.2 Des 2020, hal 25-37

Rudy Kurniawan 